\title{
Effect of euglycaemic hyperinsulinaemia on gastric emptying and gastrointestinal hormone responses in normal subjects
}

\author{
M.-F. Kong ${ }^{1}$, P. King ${ }^{1}$, I. A.Macdonald ${ }^{2}$, P. E. Blackshaw ${ }^{3}$, A. C. Perkins ${ }^{3}$, E. Armstrong ${ }^{4}$, K. D. Buchanan ${ }^{4}$, \\ R.B.Tattersall ${ }^{1}$ \\ ${ }^{1}$ Diabetes Unit, University Hospital, Queen's Medical Centre, Nottingham, UK \\ ${ }^{2}$ School of Biomedical Sciences, University of Nottingham Medical School, Nottingham, UK \\ ${ }^{3}$ Department of Medical Physics, University Hospital Nottingham and University of Nottingham Medical School, \\ Nottingham, UK \\ ${ }^{4}$ Department of Medicine, Royal Victoria Hospital, Belfast, UK
}

\begin{abstract}
Summary Several studies have shown that hyperglycaemia slows gastric emptying in normal subjects and patients with diabetes mellitus but whether hyperinsulinaemia per se has an effect remains debatable. In the present study we have assessed the effect of hyperinsulinaemia on gastric emptying of a solid and liquid meal in normal subjects. Ten men were studied three times in random order. After an overnight fast, subjects were infused with $0.9 \% \mathrm{NaCl}$ on two occasions and on the third with insulin, at $40 \mathrm{mU} \cdot \mathrm{m}^{-2} \cdot \mathrm{min}^{-1}$ with $20 \%$ glucose simultaneously to maintain euglycaemia. Steady-state glucose infusion rate was ensured before the subjects ate a standard meal of a pancake labelled with ${ }^{99 \mathrm{~m}} \mathrm{Tc}$ and milkshake labelled with ${ }^{111}$ In-DTPA. Gamma-scintigraphic images were then obtained every $20 \mathrm{~min}$ for the next $3 \mathrm{~h}$. There were no significant differences be-
\end{abstract}

tween the mean half-emptying times $\left(\mathrm{T}_{50}\right)$ of the solid and liquid during the two saline infusions (129.6 \pm $28.5 \mathrm{vs} 128.4 \pm 23.8 \mathrm{~min}$ for the solid and $25.4 \pm 7.0 \mathrm{vs}$ $34.7 \pm 18.0$ min for the liquid, mean \pm SD). Hyperinsulinaemia delayed both solid (mean $\mathrm{T}_{50} 149.6 \pm$ $30.7, p=0.031$ ) and liquid emptying (mean $\mathrm{T}_{50} 39.8 \pm$ $13.9, p=0.042$ ). There were no significant differences in the cholecystokinin and glucagon-like peptide 1 responses to the meal during either saline or insulin infusions. There was a tendency towards a greater insulin response to the meal during the hyperinsulinaemic study. Thus, hyperinsulinaemia delayed emptying of both the solid and liquid components of the meal. [Diabetologia (1998) 41: 474-481]

Keywords Gastric emptying, euglycaemia, hyperinsulinaemia, amylin, intestinal hormones.
Gastric emptying of solid and/or nutrient liquid meals is delayed in up to $50 \%$ of patients with longstanding diabetes mellitus [1]. In addition, the blood glucose response to oral carbohydrate is related to the rate of gastric emptying of a carbohydrate load in both normal subjects and patients with diabetes. Gastric emptying may therefore be a previously under-recognized contributor to variations in glycaemic control which can have an impact on the manage-

Received: 22 July 1997 and in revised form: 3 December 1997

Corresponding author: Professor I. A. Macdonald, School of Biomedical Sciences, University of Nottingham Medical School, Nottingham NG7 2UH, UK

Abbreviations: AUC, Area under the curve; ROIs, regions of interest; $\mathrm{CV}$, coefficient of variation; $\mathrm{T}_{50}$, half-emptying time; GLP-1, glucagon-like peptide-1; CCK, cholecystokinin. ment of patients with diabetes. Thus an understanding of the various factors influencing gastric emptying is important.

Hyperglycaemia delays gastric emptying in both patients with diabetes and in healthy subjects [2-4]. The mechanisms involved are uncertain, but concomitant hyperinsulinaemia may have some effect. Eliasson et al. [5] reported that gastric emptying was slower during hyperinsulinaemia but only four subjects were studied and only a solid meal was used. Ideally, both solid and nutrient-liquid emptying should be measured because it is not unusual for an emptying abnormality to be limited to either the solid or liquid component of a meal. In the normal state, solids empty differently from liquids; emptying of solids is thought to be a function of propulsive and retropulsive mincing action of the antrum whereas liquid emptying seems to depend primarily on gastric tone $[6,7]$. 


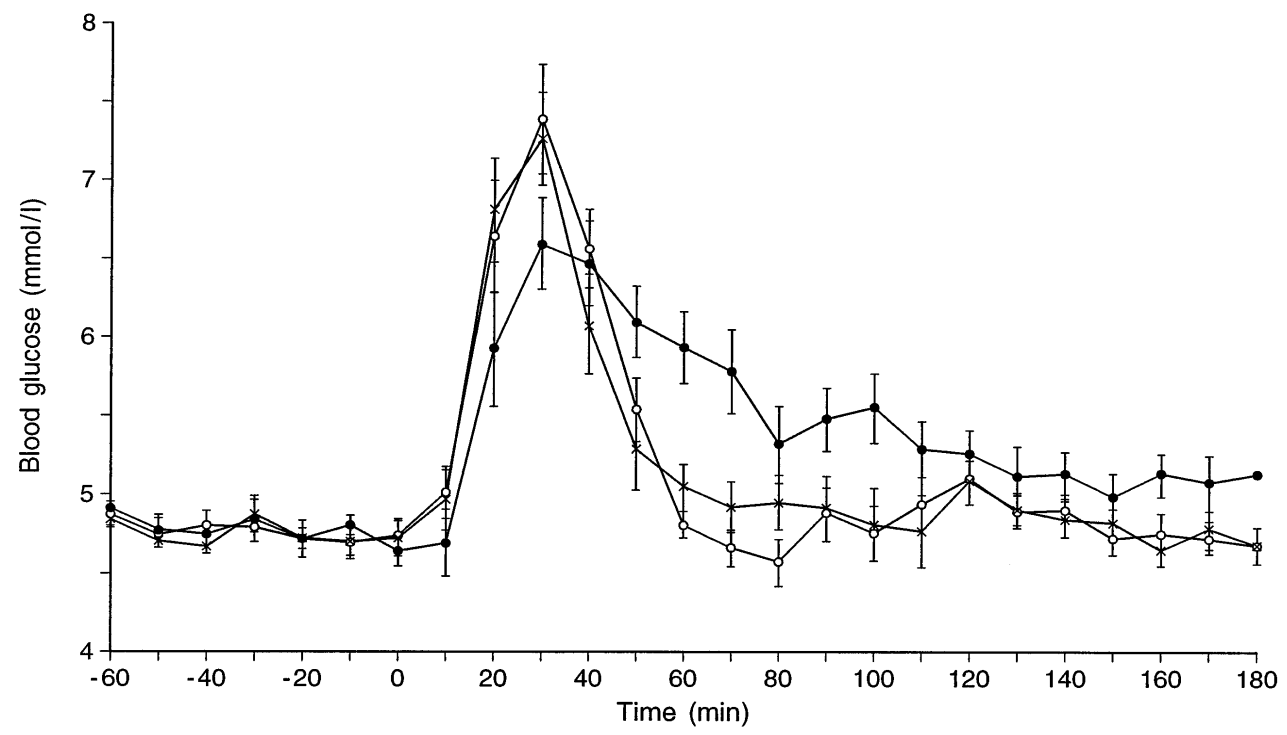

Fig. 1. Blood glucose during control experiments $(-\mathrm{x}-$ and $-\mathrm{O}-)$ and hyperinsulinaemia $(-\bullet)$. There was no difference in the peak glucose values ( 7.3 vs $6.6 \mathrm{mmol} / \mathrm{l}, p=0.068)$ or in the time to reach peak levels during either the control or insulin experiments. It took longer for the blood glucose to return to baseline during the hyperinsulinaemic experiment $(p=0.022)$

The purpose of the present study was to investigate the effect of euglycaemic hyperinsulinaemia on gastric emptying of a mixed solid and nutrient-liquid meal in non-diabetic subjects. Intestinal hormones such as cholecystokinin (CCK) and glucagon-like peptide-1 (GLP-1) can affect gastric emptying [8-12], so the effect of hyperinsulinaemia on the responses of these hormones to a test meal was also determined. Amylin, co-secreted with insulin [13], may affect gastric emptying [14] and its response to the meal was also examined.

\section{Subjects and methods}

Subjects. Ten healthy male volunteers (weight $79.2 \pm 8.2 \mathrm{~kg}$, range $61.8-86.5$, BMI $25.5 \pm 2.5 \mathrm{~kg} / \mathrm{m}^{2}$, mean $\pm \mathrm{SD}$ ), aged $23.6 \pm 3.4$ years (mean $\pm \mathrm{SD}$, range 20-32) were recruited. None reported gastrointestinal symptoms, had a past history of gastrointestinal surgery, or were on regular medication. They were asked to abstain from smoking, alcohol and caffeine for at least $18 \mathrm{~h}$ prior to the test. Informed consent was obtained from all subjects. The study was approved by the British Department of Health (Administration of Radioactive Substances Advisory Committee) and the ethics committee of the Medical School, University of Nottingham.

Protocol. Each subject had three gastric emptying studies in random order, separated by at least 1 week. On one visit a euglycaemic, hyperinsulinaemic clamp was performed and on the other two $0.9 \% \mathrm{NaCl}$ was infused i.v. as a control and to assess reproducibility of the gastric emptying measurements. Subjects arrived at $08.30 \mathrm{~h}$ after fasting overnight. A cannula was inserted into an antecubital vein for infusion of $0.9 \%$ $\mathrm{NaCl}$ or glucose/insulin. Another cannula was inserted retrogradely into a vein on the dorsum of the dominant hand and it was kept patent with a slow infusion of $0.9 \% \mathrm{NaCl}$. The hand rested in a heated box $\left(55-60^{\circ} \mathrm{C}\right)$ to obtain "arterialized" venous blood samples.

Low activity radioactive anatomical markers $\left({ }^{99 \mathrm{~m}} \mathrm{Tc}\right)$ were attached to the surface of the subject's skin, anteriorly and posteriorly. At 0 min the subjects ate a standard meal within a $10 \mathrm{~min}$ period, consisting of a pancake ( $46 \%$ carbohydrate, $26 \%$ fat, $10 \%$ protein), labelled with $3 \mathrm{MBq}$ non-absorbable ${ }^{99} \mathrm{~m}$ Tc tin colloid, and a low fat milkshake $(11 \%$ carbohydrate, $4 \%$ fat, $3 \%$ protein), labelled with $0.5 \mathrm{MBq}$ non-absorbable ${ }^{111}$ In-DTPA, providing a total of $400 \mathrm{kcal}$ (the milkshake containing $69 \mathrm{kcal})$. Gastric emptying images were obtained for the next $3 \mathrm{~h}$. Between standing image acquisitions, the subjects were allowed to sit.

Gastric emptying data were acquired every $20 \mathrm{~min}$ with $30 \mathrm{~s}$ anterior and posterior images of the stomach [15] using an IGE maxi-camera II gamma camera (IGE Medical Systems, Slough, UK) fitted with a medium-energy general purpose collimator. The gamma camera was linked to a dedicated Nuclear Diagnostics computer system. Regions of interest (ROIs) were created around the computer generated image of the stomach for both anterior and posterior images, and counts were recorded. The geometric mean of the anterior and posterior measurements was calculated and counts corrected for background radiation, isotope decay and cross talk between the energy windows. An ROI was drawn around the total stomach, which was subsequently divided into proximal and distal regions - the proximal region corresponding to the fundus and proximal corpus and the distal region representing the antrum and distal corpus. For each of the three ROIs (proximal, distal and total stomach), activity time curves, expressed as a percentage of total meal against time, were derived and the time for $50 \%$ emptying $\left(\mathrm{T}_{50}\right)$ was calculated. The coefficient of variation $(\mathrm{CV})$ for solid $\mathrm{T}_{50}$ in normal subjects is $13 \%$ and for liquid $\mathrm{T}_{50}$ the $\mathrm{CV}$ is $28 \%$ [16].

Euglycaemic, hyperinsulinaemic clamping studies were performed according to the method of De Fronzo et al. [17]. Short-acting insulin (Human Actrapid; Novo Nordisk, Copenhagen, Denmark) was dissolved in $0.9 \% \mathrm{NaCl}$, containing $2 \mathrm{ml}$ of the subject's blood, to a concentration of $1 \mathrm{U} / \mathrm{ml}$. The infusion rate was $40 \mathrm{mU} \cdot \mathrm{m}^{-2} \cdot \mathrm{min}^{-1}$. Glucose was infused concomitantly to maintain the blood glucose at $4.5-5.0 \mathrm{mmol} /$ 


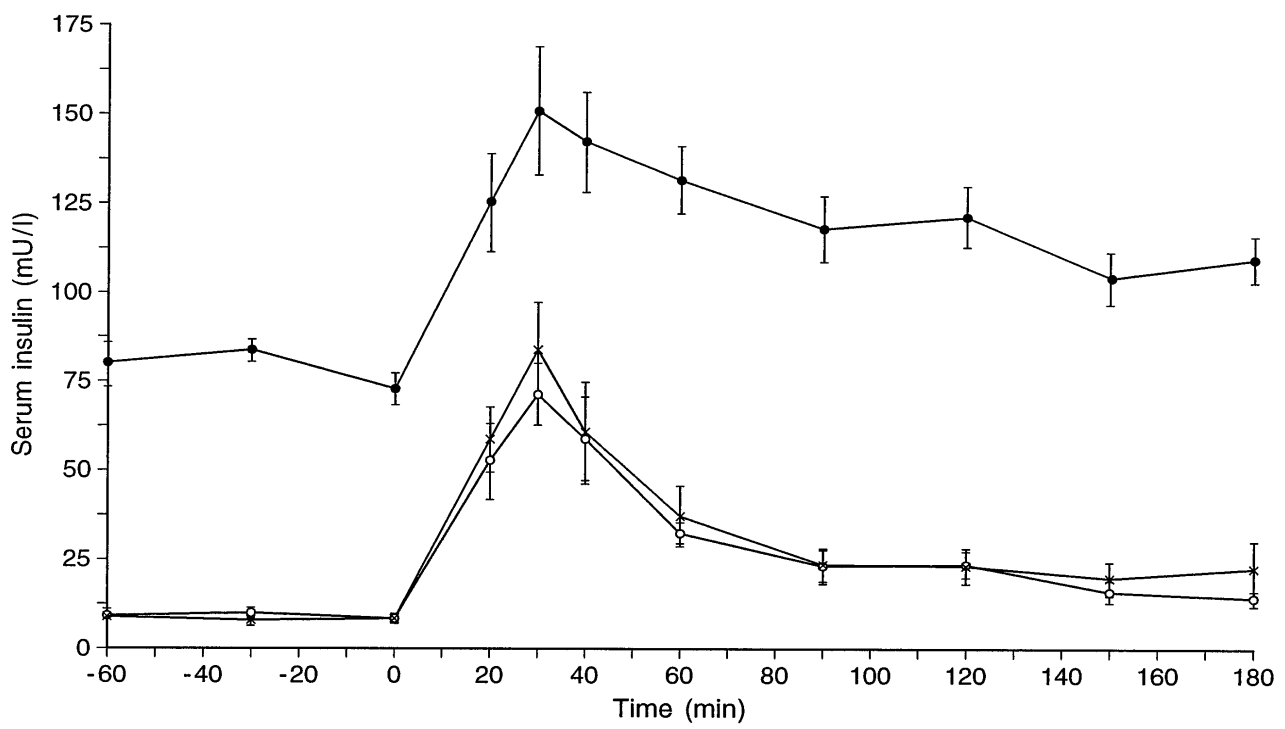

Fig. 2. Serum insulin during control experiments $(-x-$ and $-0-)$ and hyperinsulinaemia $(-\bullet)$. Insulin values remained elevated above pre-meal values for longer during the hyperinsulinaemic experiment $(p=0.047)$

1 for at least $60 \mathrm{~min}$ before the subjects ate the standardized meal, to ensure steady-state glucose infusion rate. The glucose and insulin infusion rates were then continued for the remainder of the study period at the rates established during the first hour. The infusion rates for saline during the control experiments were matched as closely as possible to the expected glucose infusion rate during the clamp. Blood glucose concentra-

Fig. 3. C-peptide during control experiments $(-\mathrm{x}-$ and $-\mathrm{O}-)$ and hyperinsulinaemia $(-\bullet)$. C-peptide values remained elevated above pre-meal values for longer during the hyperinsulinaemic experiment $(p=0.015)$. As expected, there was an initial decline in C-peptide levels during the hyperinsulinaemic experiment tions were measured every $10 \mathrm{~min}$ with a glucose oxidase method using a Yellow Springs Analyser (Yellow Springs, Ohio, USA); CV for the assay was $3 \%$. Blood was drawn at $-30,0,20,30,40,60,90,120,150$ and $180 \mathrm{~min}$ for insulin, CCK, GLP-1 and amylin concentrations.

Assays. Insulin was measured by radioimmunoassay (Diagnostic Products Corporation, Los Angeles, Calif., USA, inter-assay CV $7.4 \%$ at $114 \mathrm{mU} / \mathrm{l}$ ).

C-peptide was assayed by ELISA based on two monoclonal antibodies (Dako Diagnostics Ltd, Ely, Cambridgeshire, UK). The lower limit of detection was less than $0.05 \mathrm{nmol} / \mathrm{l}$. The inter-assay CV was 3.87-8.2\%.

GLP-1 was measured in extracts of serum by radioimmunoassay with synthetic GLP-1 (7-36) amide [Bachem] as the assay standard, antibody code R 600-8 (final dilution $1: 30000$ ), and synthetic GLP-1 labelled by chloramine-T method and purified by reverse phase high-performance liquid chromatography. The antiserum used did not cross-react with other known gut and brain peptides. The sensitivity of the assay was $9 \mathrm{pmol} / \mathrm{l}(30 \mathrm{pg} / \mathrm{ml})$; the inter-assay $\mathrm{CV}$ was $11 \%$ and the intra-assay $\mathrm{CV}$ was $8 \%$ at $45 \mathrm{pmol} / \mathrm{l}(150 \mathrm{pg} /$ $\mathrm{ml})$.

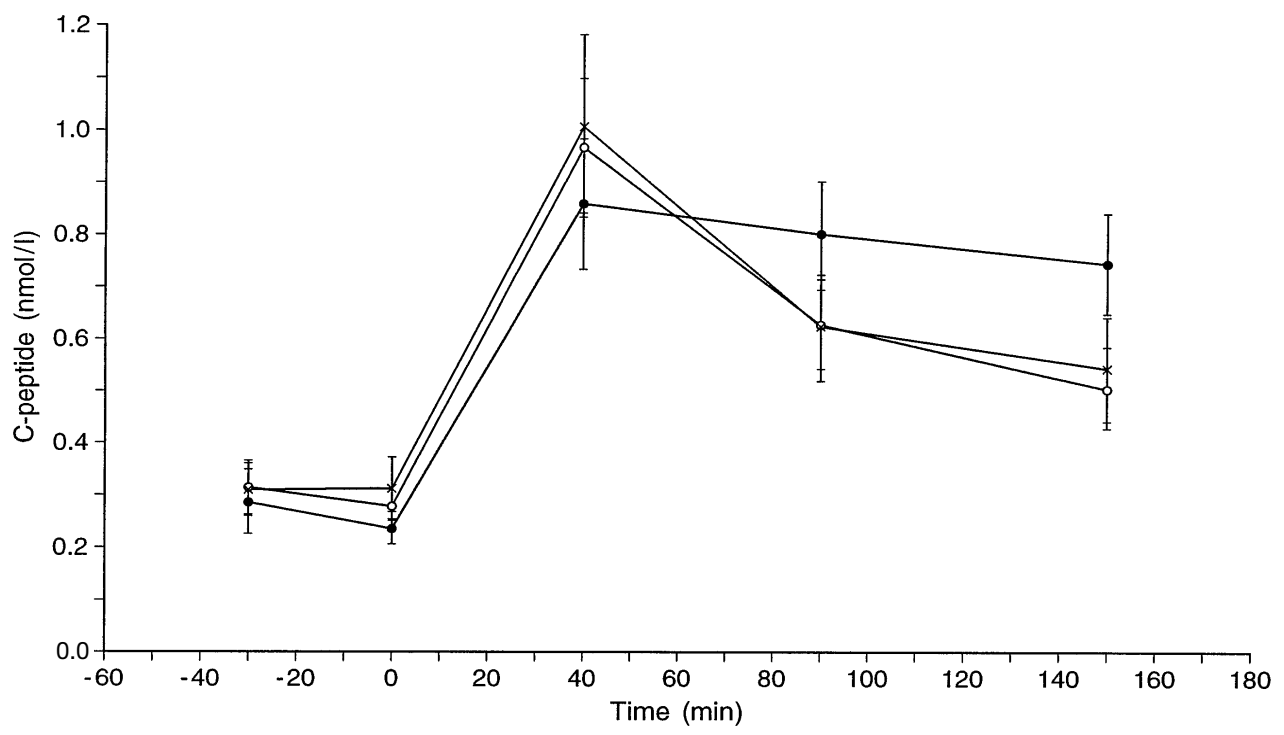



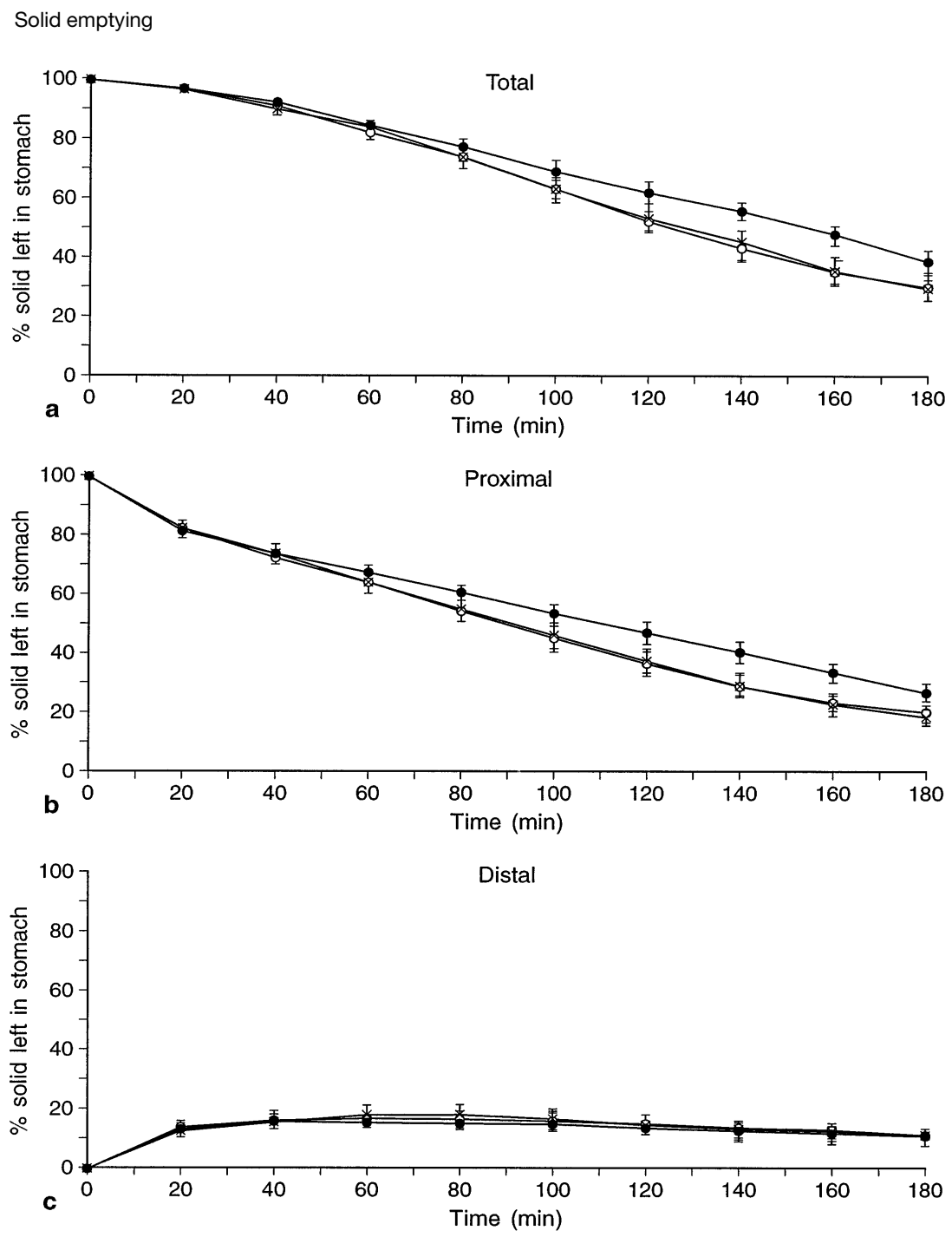

Fig. 4a-c. Solid gastric emptying during control experiments $(-\mathrm{X}-$ and $-\mathrm{O}-)$ and hyperinsulinaemia $(-\bullet)$. Data are mean \pm SEM. There were no significant differences between the mean half-emptying times $\left(\mathrm{T}_{50}\right)$ during the two saline infusions $(129.6 \pm 28.5$ vs $128.4 \pm 23.8$ min, mean \pm SD). Hyperinsulinaemia resulted in a delay in emptying (mean $\mathrm{T}_{50} 149.6 \pm$ $30.7, p=0.031)$. $\mathrm{T}_{50}$ is defined as the time at which $50 \%$ of the isotope had left the stomach. The slower emptying of the solid component during hyperinsulinaemia could be explained by retention in the proximal stomach (b). There was no difference between the saline and insulin infusions for retention in the distal stomach (c)

CCK was measured by radioimmunoassay with synthetic CCK8 (sulphated) [Bachem] as the assay standard, antibody code R7 [3] (final dilution $1: 100000$ ). Serum was extracted using ethanol, shaken, centrifuged and the supernatant dried under an air stream. This was reconstituted in $500 \mu$ lassay buffer (phosphate buffer $0.04 \mathrm{~mol} / \mathrm{l}+0.2 \mathrm{~g} \%$ gelatin and $0.16 \mathrm{~g} \%$ EDTA). Bolton \& Hunter labelled ${ }^{125} \mathrm{I}-\mathrm{CCK} 8 \mathrm{~s}$ radiolabel (Amersham) and antiserum, raised in rabbit to CCK8s, conjugated to ovalbumin using carbodiimide, were used. The intra- assay $\mathrm{CV}$ was 8.2 and $6.6 \%$ at $5 \mathrm{ng} / \mathrm{l}$ and $15 \mathrm{ng} / \mathrm{l}$, respectively and the inter-assay $\mathrm{CV}$ was 13.3 and $11.5 \%$ at $5 \mathrm{ng} / \mathrm{l}$ and $15 \mathrm{ng} / \mathrm{l}$, respectively with lower limit of detection of $1.5 \mathrm{ng} / \mathrm{l}$. The relative cross-reactivity with gastrin 17, pentagastrin, $\mathrm{CCK} /$ gastrin 4 was less than 0.001 .

Amylin and amylin-like peptides were measured using twosite sandwich ELISA with capture antibodies F024 and F002, respectively (Amylin Pharmaceuticals Inc., San Diego, Calif., USA). Interassay CVs were less than $15 \%$ across the assay range. Minimum detectable amylin and amylin-like peptide concentrations were 1.9 and $2.7 \mathrm{pmol} / \mathrm{l}$.

Statistical analysis. Conventional methods were used to measure means, SEM and SD. The order of the two control experiments was randomized and the results were analysed using three-way ANOVA. The gastric emptying curves and all biochemical data were analysed using Repeated Measures Analysis of Variance; 'treatment-time' interactions were evaluated to determine the effect of insulin as compared with saline over time. A $p$ value less than 0.05 was considered significant in all analyses. 

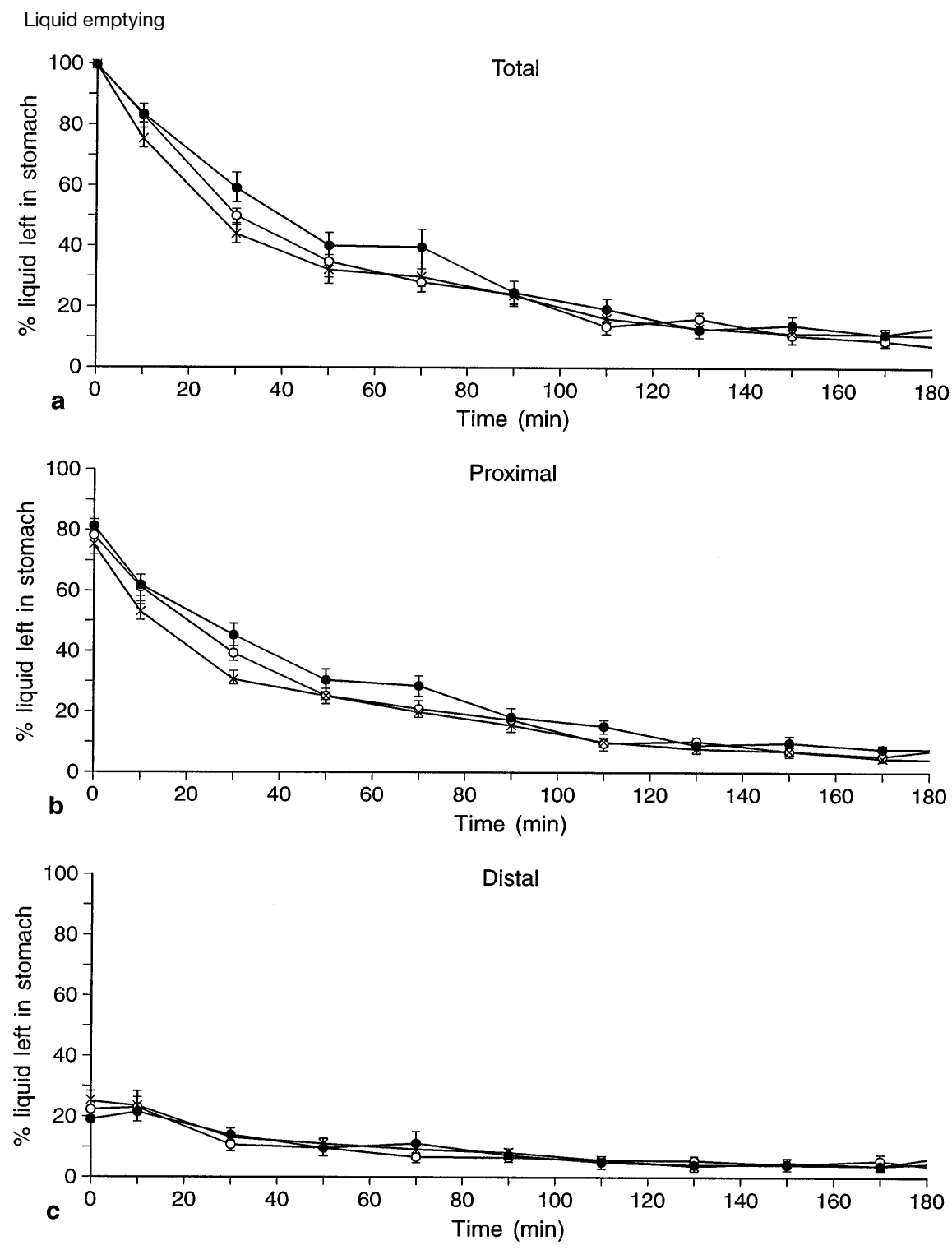

Fig. 5 a-c. Liquid emptying during control experiments $(-\mathrm{x}-$ and $\left.-\mathrm{O}_{-}\right)$and hyperinsulinaemia $(-\bullet)$. Data are mean \pm SEM. There were no significant differences between the mean $\mathrm{T}_{50}$ of the liquid during the two saline infusions $(25.4 \pm 7.0$ vs $34.7 \pm 18.0 \mathrm{~min}$, mean $\pm \mathrm{SD}$ ). Hyperinsulinaemia also delayed liquid emptying (mean $\mathrm{T}_{50} 39.8 \pm 13.9, p=0.042$ ). The slower emptying of the liquid component during hyperinsulinaemia could be explained by retention in the proximal stomach (b). There was no difference between the saline and insulin infusions for retention in the distal stomach (c)

\section{Results}

Blood glucose, insulin and C-peptide. There was no difference in the blood glucose profile during the two control experiments. There was no difference in the peak glucose values $(7.3 \mathrm{vs} 6.6 \mathrm{mmol} / \mathrm{l}, p=0.068)$ or in the time to reach peak values during either the $\mathrm{NaCl}$ or insulin experiments (Fig.1). It took longer for the blood glucose level to return to baseline during the hyperinsulinaemic experiment $(p=0.022)$. The area under the curve (AUC) of the blood glucose response was not significantly different during the saline and insulin experiments $(828.5 \pm 48.25$ vs $1523 \pm$ $99.24 \mathrm{mmol} / \mathrm{l}$.min respectively, $p=0.107)$. However, the AUC from time 40-180 min was greater during the insulin experiment compared to the saline experiment $(1192 \pm 89.1$ vs $344.5 \pm 46.4 \mathrm{mmol} / 1 . \mathrm{min}, p=$ $0.04)$.

The insulin and C-peptide profiles (Figs. 2 and 3) mirrored the glucose profile and were almost identical during the two control experiments. Insulin and C-peptide levels remained elevated above pre-meal values for longer during the hyperinsulinaemic experiment ( $p=0.047$ for insulin and $p=0.015$ for C-peptide). There was no significant difference in the absolute rise (postprandial peak values minus preprandial values) in insulin concentrations between the saline $(75.3 \pm 29.8 \mathrm{mU} / \mathrm{l})$ and insulin $(97 \pm 39.8 \mathrm{mU} / \mathrm{l})$ exper- 
Table 1. Responses of CCK and GLP-1 to saline and insulin infusions

\begin{tabular}{lllllll}
\hline & \multicolumn{2}{l}{ CCK $(\mathrm{ng} / \mathrm{l})$} & & \multicolumn{3}{l}{ GLP-1 $(\mathrm{ng} / \mathrm{l})$} \\
\cline { 2 - 3 } \cline { 5 - 7 } & Control & Insulin & & Control & \multicolumn{2}{l}{ Insulin } \\
\hline 0 min value & $14.8 \pm 0.9$ & $12.4 \pm 6.7$ & & $143 \pm 2.8$ & 123 & \pm 43.2 \\
$\begin{array}{l}\text { Peak value } \\
\text { Mean post- }\end{array}$ & $16.2 \pm 1.6$ & $16.1 \pm 6.8$ & & $160.1 \pm 10.1$ & 144 & \pm 41.6 \\
prandial value & $13.8 \pm 1.3$ & $14.7 \pm 0.9$ & & $143.4 \pm 10.3$ & $122.4 \pm 13.2$ \\
\hline
\end{tabular}

Data are mean \pm SD

iments $(p=0.102)$. As expected, there was an initial decline in C-peptide levels during the hyperinsulinaemic experiment.

Solid and liquid emptying. There were no significant differences between the mean half-emptying times $\left(\mathrm{T}_{50}\right)$ of the solid and liquid during the two saline infusions $(129.6 \pm 28.5$ vs $128.4 \pm 23.8 \mathrm{~min}$ for the solid and $25.4 \pm 7.0$ vs $34.7 \pm 18.0 \mathrm{~min}$ for the liquid, mean \pm SD). Hyperinsulinaemia delayed both solid (mean $\mathrm{T}_{50} 149.6 \pm 30.7, p=0.031$ ) and liquid emptying (mean $\mathrm{T}_{50} 39.8 \pm 13.9, p=0.042$ ). For eight subjects the $\mathrm{T}_{50}$ during the hyperinsulinaemic experiment was slower than the $T_{50}$ during both saline experiments and for two subjects it was between the two saline experiments. There was good reproducibility of both solid and liquid gastric emptying; the means \pm SD of the difference between the two separate days' $\mathrm{T}_{50}$ were $15.3 \pm 21.9 \mathrm{~min}$ for the solid and $-5.1 \pm 19.7 \mathrm{~min}$ for the liquid.

The slower emptying of both solid and liquid components of the meal during hyperinsulinaemia could be explained by retention in the proximal stomach (Figs. 4b, 5b). There was no difference between the saline and insulin infusions for retention in the distal stomach (Figs. 4c, 5c).

Gastrointestinal hormones. There were no significant differences in the CCK and GLP-1 responses after the meal during either saline or insulin infusions ( $p=0.249$ and $p=0.242$, respectively). For CCK, the $0 \mathrm{~min}$ value was $14.8 \mathrm{ng} / \mathrm{l}$ during the saline experiments and $12.4 \mathrm{ng} / \mathrm{l}$ during the insulin experiment. This rose to $16.2 \mathrm{ng} / \mathrm{l}$ at $120 \mathrm{~min}$ during the saline experiments and $16.1 \mathrm{ng} / \mathrm{l}$ at $180 \mathrm{~min}$ during the insulin experiment. For GLP-1 the 0 min value was $143 \mathrm{ng} / \mathrm{l}$ during the saline experiments and $123 \mathrm{ng} / \mathrm{l}$ during the insulin experiment (Table 1). There was no evidence of a GLP-1 response to the test meal on either occasion.

There was a greater amylin response during the hyperinsulinaemic clamp compared to the saline infusions ( $p=0.017, \mathrm{~F} 024$ assay; $p<0.001, \mathrm{~F} 002$ assay). Figure 6 shows the amylin profile. The amylin-like peptide profile (not shown) was similar to the amylin profile. The $0 \mathrm{~min}$ amylin value was $3.4 \mathrm{pmol} / \mathrm{l}$ during the saline experiments and $3.7 \mathrm{pmol} / \mathrm{l}$ during the insu- lin experiment. This rose to a peak value of $8.4 \mathrm{pmol} / 1$ at $30 \mathrm{~min}$ during the saline experiments and $9.5 \mathrm{pmol} /$ 1 at $60 \mathrm{~min}$ during the insulin experiment. The $0 \mathrm{~min}$ amylin-like peptide value was $6.8 \mathrm{pmol} / \mathrm{l}$ during the saline experiments and $6.5 \mathrm{pmol} / \mathrm{l}$ during the insulin experiment. This rose to a peak value of $21.4 \mathrm{pmol} / 1$ at $40 \mathrm{~min}$ during the saline experiments and $19.5 \mathrm{pmol} / \mathrm{l}$ at $60 \mathrm{~min}$ during the insulin experiment.

\section{Discussion}

We found that hyperinsulinaemia delayed gastric emptying of both solid and liquid components of a meal although the effect was marginal. There was more variability of the liquid $\mathrm{T}_{50}$ during the saline experiments in individual subjects. The initial rise in blood glucose was slower during insulin infusion which could be explained by delayed gastric emptying of the carbohydrate-containing liquid. Although there was a trend towards lower peak glucose values during the hyperinsulinaemic compared to the control experiments, this failed to reach statistical significance. It took longer for blood glucose to return to baseline during the hyperinsulinaemic experiment, which may reflect prolonged glucose absorption as a result of the delay in gastric emptying. However, overall, carbohydrate absorption (as assessed by the AUC of blood glucose) was not significantly different during the saline and insulin infusions. Insulin infusion rates of $40 \mathrm{mU} \cdot \mathrm{m}^{-2} \cdot \mathrm{min}^{-1}$ and higher have been shown to suppress hepatic glucose production in young, non-diabetic subjects [18]. Thus, during the hyperinsulinaemic clamp, blood glucose after meal ingestion reflects absorbed glucose unaffected by a change in endogenous production. We also have to consider the continuous glucose infusion, which was maintained at the level required in the fasting, baseline period to achieve euglycaemia. It is unlikely that subjects would have developed insulin resistance in the postprandial period, so this infusion will not have caused a rise in blood glucose.

There is evidence that both CCK and GLP-1 [8-12] slow gastric emptying, but there was no difference in the concentrations between the saline and hyperinsulinaemic experiments. There was no evidence of a GLP-1 response to the test meal on either occasion, and while there were some fluctuations in CCK after the meal, mean concentrations in the postprandial period did not exceed baseline values. It is surprising that we failed to see significant elevations in these gut peptides, although the low fat and low energy contents of the meal are likely to have contributed to this observation.

The amylin response following the meal mirrored the insulin and blood glucose profiles. The postprandial amylin response was significantly greater during the hyperinsulinaemic experiment. Amylin is co-se- 


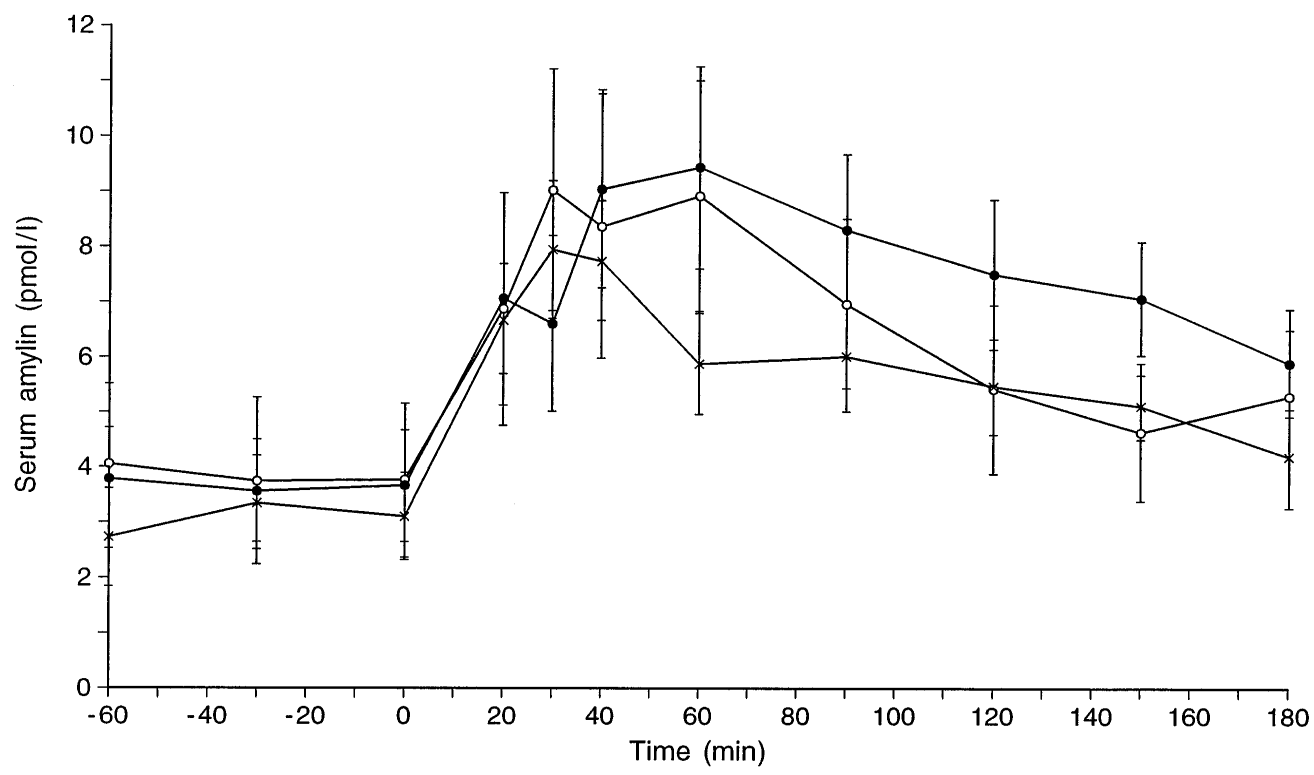

Fig. 6. Serum amylin during control experiments $(-\mathrm{x}-$ and $-\mathrm{O}-)$ and hyperinsulinaemia $(-\bullet)$. There was a greater amylin response during hyperinsulinaemia compared to control experiments $(p=0.017)$

creted with insulin from the beta cells of the pancreas. There is recent evidence that amylin delays gastric emptying [14]. There may be an interaction between insulin and amylin and they both serve to slow gastric emptying.

It is interesting that the beta-cell response to food was not inhibited by $1 \mathrm{~h}$ of antecedent hyperinsulinaemia; following the meal both C-peptide and insulin were released although as expected there was an initial fall in the C-peptide levels before the meal, during induction of hyperinsulinaemia. Eliasson et al. [5] reported similar findings in their study.

How insulin delays gastric emptying of solids and liquids is unclear. Eliasson et al. [5] found that euglycaemic hyperinsulinaemia reduced postabsorptive motility in the antrum and proximal duodenum (loss of antral phase III of the migrating motor complex in the gastric antrum and decreased pressure waves in the duodenum) after a solid meal. However, Hasler et al. [19] have recently reported that antral motility after a mixed solid-liquid meal was reduced by hyperglycaemia but not by euglycaemic hyperinsulinaemia [19]. However, the insulin infusion rate used was $80 \mathrm{mU} \cdot \mathrm{m}^{-2} \cdot \mathrm{min}^{-1}$, the fasting plasma insulin concentration was $133 \pm 11 \mathrm{mU} / \mathrm{l}$ and the postprandial value achieved was $195 \pm 29 \mathrm{mU} / \mathrm{l}$, compared to baseline serum insulin of $72.8 \pm 14.4 \mathrm{mU} / \mathrm{l}$ and peak value of $151.3 \pm 56.3 \mathrm{mU} / \mathrm{l}$ in our study.

In this study, the delayed emptying of both solid and liquid components of the meal by hyperinsulinaemia could be explained by their retention in the proximal stomach. We could attempt to explain this by postulating that insulin may produce a delay in emptying by affecting proximal stomach motility. Motility studies are needed to confirm this.

Non-insulin-dependent diabetic patients are often insulin resistant and hyperinsulinaemic [20] and have been shown to have a delayed glucose peak following a meal [2]. Our study suggests that hyperinsulinaemia may account for this by altering the carbohydrate absorption pattern and studies in such patients are needed.

Acknowledgements. We thank Ms. Carolyn Caldwell (Department of Medicine, Royal Victoria Hospital, Belfast, UK) for technical assistance for the GLP-1 assays, Mr. Paddy Riley (Cripps computing centre, University of Nottingham, Nottingham, UK) for statistical advice, Dr. Martin Payne (Oxford Diabetes Research Laboratories, Oxford, UK) and Amylin Pharmaceuticals \& Amylin Europe Ltd (Oxford, UK) for the amylin and ALP assays and Professor Michael Horowitz and Ms. Karen Jones (Department of Medicine, Royal Adelaide Hospital, Adelaide, South Australia) for useful advice.

\section{References}

1. Horowitz M, Fraser R (1994) Disordered gastric motor function in diabetes mellitus. Diabetologia 37: 543-551

2. Horowitz M, Harding P, Maddox AF et al. (1989) Gastric and oesophageal emptying in patients with type 2 (non-insulin-dependent) diabetes mellitus. Diabetologia 32: 151-159

3. Fraser R, Horowitz M, Maddox A, Harding P, Chatterton B, Dent J (1990) Hyperglycaemia slows gastric emptying in type 1 (insulin-dependent) diabetes mellitus. Diabetologia 33: 675-680

4. MacGregor I, Gueller R, Watts H, Meyer J (1976) The effects of acute hyperglycaemia on gastric emptying in man. Gastroenterology 70: 190-196

5. Eliasson B, Björnsson E, Urbanavicius V et al. (1995) Hyperinsulinaemia impairs gastrointestinal motility and slows carbohydrate absorption. Diabetologia 38: 79-85 
6. Horowitz M, Harding PE, Maddox A et al. (1986) Gastric and oesophageal emptying in insulin-dependent diabetes mellitus. J Gastroenterol Hepatol 1: 97-113

7. Rees WDW, Miller LJ, Malagelada JR (1980) Dyspepsia, antral motor dysfunction, and gastric stasis of solids. Gastroenterology 78: 360-365

8. Liddle RA, Rushakoff RJ, Morita ET, Beccaria L, Carter JD, Goldfine ID (1988) Physiological role for cholecystokinin in reducing postprandial hyperglycaemia in humans. $\mathrm{J}$ Clin Invest 81: 1675-1681

9. Liddle RA, Morita ET, Conrad CK, Williams JA (1986) Regulation of gastric emptying in humans by cholecystokinin. J Clin Invest 77: 992-996

10. Wettergren A, Schjoldager B, Mortensen PE, Myhre J, Christiansen J, Holst JJ (1993) Truncated GLP-1 (proglucagon 78-107-amide) inhibits gastric and pancreatic functions in man. Dig Dis Sci 38: 665-673

11. Gutniak M, Ørskov C, Holst JJ, Ahren B, Efendic S (1992) Antidiabetogenic effect of glucagon-like peptide-1 [7-36 amide] in normal subjects and patients with diabetes. N Engl J Med 326: 1316-1322

12. Dupre J, Behme MT, Hramiak IM et al. (1995) Glucagonlike peptide 1 reduces postprandial glycaemic excursions in IDDM. Diabetes 44: 626-630

13. Cooper GJS, Willis AC, Clark A, Turner RC, Sim RB, Reid KB (1987) Purification and characterization of a pep- tide from amyloid-rich pancreases of type 2 diabetic patients. Proc Natl Acad Sci USA 84: 8628-8632

14. Kong M-F, King P, Macdonald IA et al. (1997) Infusion of pramlintide, a human amylin analogue, delays gastric emptying in men with IDDM. Diabetologia 40: 82-88

15. Hardy JG, Perkins AC (1985) Validity of the geometric mean correction in the quantification of whole bowel transit. Nucl Med Commun 6: 217-224

16. Kong M-F, Perkins AC, King P, Blackshaw PE, Macdonald IA Reproducibility of gastric emptying of a pancake and milkshake meal in normal subjects. Nucl Med Commun (in press)

17. DeFronzo RA, Tobin JD, Andres R (1979) Glucose clamp technique: a method for quantifying insulin secretion and resistance. Am J Physiol 237: E214-E223

18. Prager R, Wallace P, Olefsky JM (1986) In vivo kinetics of insulin action on peripheral glucose disposal and hepatic glucose output in normal and obese subjects. J Clin Invest 78: 472-481

19. Hasler WL, Soudah HC, Dulai G, Owgang C (1995) Mediation of hyperglycaemia-induced gastric slow-wave dysrhythmias by endogenous prostaglandins. Gastroenterology 108: 727-736

20. Reaven GM (1988) Role of insulin resistance in human disease. Diabetes 37: 1595-1607 